\title{
Factors affecting safety of handling ultra large container vessels in Port of Gdańsk
}

JEL: R41 DOI: 10.24136/atest.2019.057

Data zgłoszenia: 15.12.2018 Data akceptacji: 08.02.2019

Paper discussed important factors affecting handling of ULCS (ultra large container ships) in Port of Gdańsk. In recent years more such vessels had been calling Gdańsk, including new generation o ULCS called Triple-E launched by Maersk. Studies conducted in Maritime University confirmed feasibility of safe handling of such large vessels but pointed to several factors needed to be taken under consideration to provide required safety level for ship handling operations. Author analysed factors responsible for safe handling ULCs in Gdańsk.

Keywords: Gdańsk, container ship, shiphandling.

\section{Introduction}

Development of Gdańsk Outer Port into large container hub attracted attention of shipping lines running largest container vessels on route between Europe and Far East. Such vessels began more frequently entering Baltic Sea with destination Port of Gdańsk. Existing approaching fairway had to be upgraded to provide safe entry into harbour basin and turntables for largest container vessels were provided. Port Authorities also planned construction of second deep water container wharf, in addition to existing one, with purpose to increase existing cargo handling capacity, as shown below:

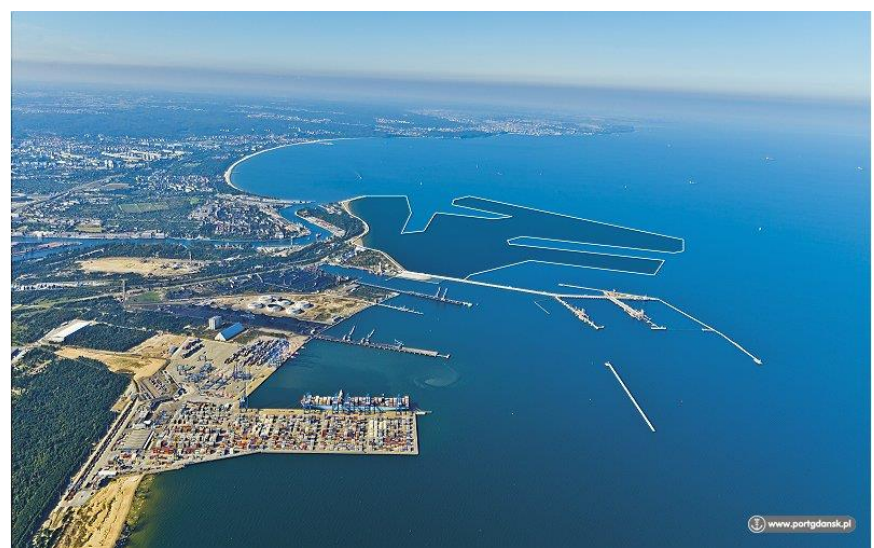

Fig. 1. Outer Port of Gdańsk with newly build container quay. [6]
Modifications were made with consideration to new generation of ULCS being on the building staples at that time, and expected to start regular service from Far East to Gdańsk.

\section{Port of Gdańsk Deepwater Container Terminal and its approaches \\ 1.1 Hydro-meteorological conditions}

Deepwater Container Terminal (DCT) is situated in southernwest corner of Gulf of Gdansk, in place called The Outer Port. Two most important meteorological factors as wind force and direction are varying with season. The same applies to foggy days with restricted visibility. Land offers good protection from westerly winds but harbour and its approaches are exposed to easterly winds which may disrupt port activities. Easterly winds are more likely to occur in period from January to May with highest probability of winds of force $7^{\circ}$ Beaufort and above from January to March. Statistical average of such day for these months is 2 days within a month. Wind of such force is the maximum safe limit for mooring operations of ULCS [4] but yearly average of day with wind force $7^{\circ}$ Beaufort is only 11 . Prolonged winds from same direction may induce sea currents with speed reaching 1 knot and direction depending on wind. During calm weather weak north-westerly current can be observed. Days with visibility restricted by for mostly occur during winter time and autumn with average 22 days per year.

\subsection{Approaching fairway and harbour.}

Fairway leading to Deepwater Container Terminal begins at buoy ZS and is marked at both sides with pair of buoys marked $P$ and numbered. Width of fairway with depth $17 \mathrm{~m}$ is set for $350 \mathrm{~m}$, providing safe and convenient approach for large vessels entering The Outer Port. Axis of fairway is marked by leading lights in direction $253.6^{\circ}$. Fairway is terminated by outer turntable, with width 670 $\mathrm{m}$ and minimum depth $16.5 \mathrm{~m}$, allowing turning of oil tankers entering Oil Terminal. Container vessels calling DCT are proceeding to second inner $650 \mathrm{~m}$ wide turntable, where they align to one of available berthing place and commence mooring operations. DCT has two container quays, each $650 \mathrm{~m}$ long, located at southern and western edges of basin. Terminal is dredged to depth sufficient to accommodate vessels with maximum draft $15 \mathrm{~m}$. Figure 3 shows DCT and whole Outer Port of Gdańsk are shown on nautical chart excerpt.

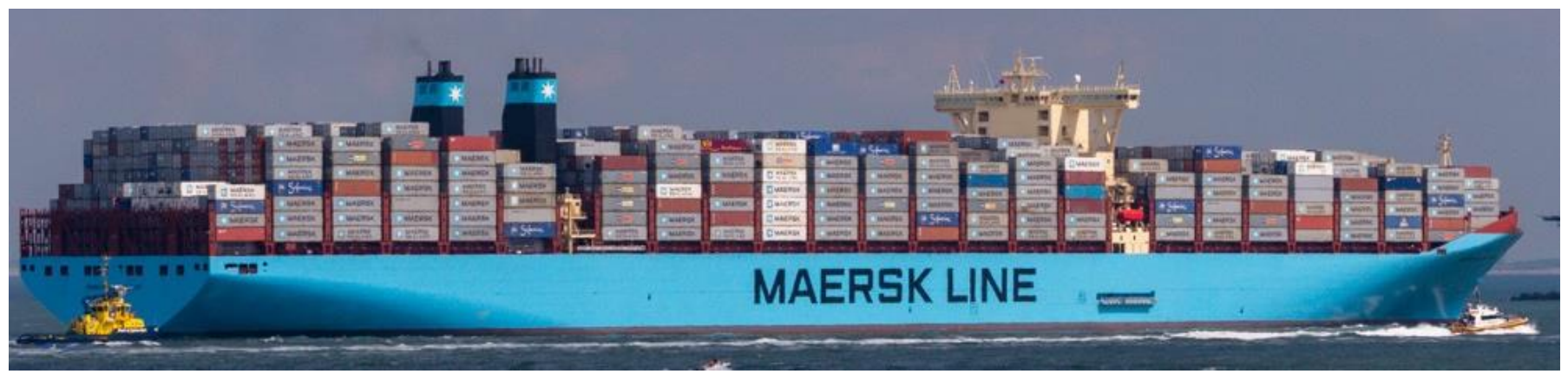

Fig. 2. First of new generation of ULCS series Triple-E Mærsk Mc-Kinney Møller [5] 


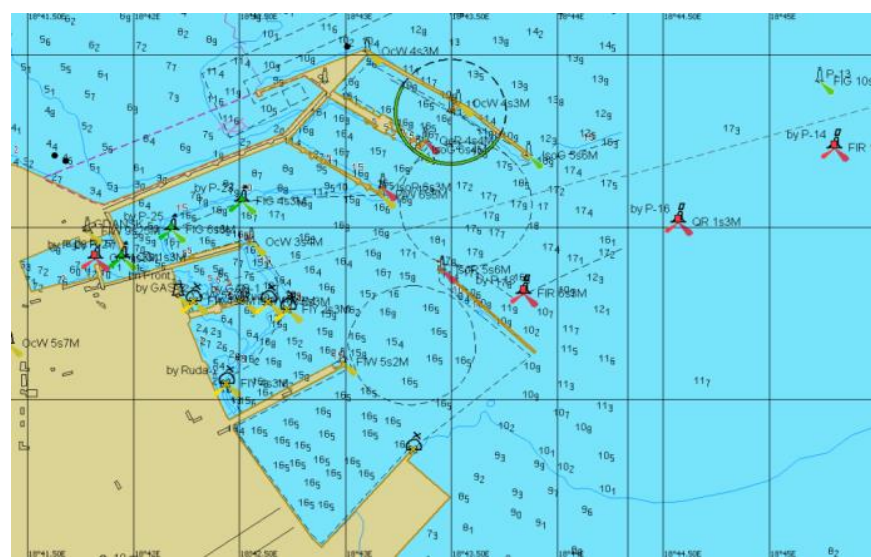

Fig. 3. Excerpt from nautical chart showing Outer Port of Gdańsk and its approaches. [4]

\section{Vessels calling DCT}

Terminal provides services to wide variety of container vessels including ULCS. Handling of such types of vessels requires thorough analysis of factors determining safety of ship handling operations at their every stage. There are two types of large container vessels being handled in DCT. First type belongs to typical ULCS driven by single fixed pitch propeller. They have tunnel thrusters fitted at bow and often at the stern to improve their manoeuvring characteristics. Their length is below $400 \mathrm{~m}$. Studies conducted in Maritime University of Gdynia concentrated on recently developed ULCS known as Triple-E class. Danish company Maersk Line developed and ordered 31 vessels of such type, with last being under construction. First generation of Triple-E, comprising 20 vessels is well suited for DCT Gdańsk. Vessel length $399 \mathrm{~m}$, with beam $59 \mathrm{~m}$ and draft $14.5 \mathrm{~m}$ allows for its safe handling at wind force $7^{\circ}$ of Beaufort scale, which equals to $17 \mathrm{~m} / \mathrm{s}$ [4]. Independents studies conducted 4 years later vessels of similar size in Sweden, have shown the same results [3]. Port of Rotterdam allows mooring operations with wind force $6^{\circ}$ Beaufort $(14 \mathrm{~m} / \mathrm{s})$ due to local conditions. Triple-E vessels despite lack of stern tunnel thrusters have good manoeuvring abilities due to twin propellers propulsion and twin rudders allowing stern movement control.

\section{Wind factor whilst underway.}

Ultra large container vessels with full complements of containers on deck have side area exposed to wind (windage area) between 13000 and $18000 \mathrm{~m}^{2}$ which means strong beam wind creates very large force acting on vessel. Wind induced lateral force can be calculated with following formula [2]:

$$
F=1 / 2 \bullet \rho_{a} \bullet C_{w} \bullet A_{w} \bullet V_{w}^{2}
$$

Where:

$\mathrm{F}$ - lateral wind force $(\mathrm{N})$

$\mathrm{C}_{\mathrm{w}}$ - wind drag coefficient, depending on configuration of above water structure

$P_{a}-$ air density $\left(\mathrm{kg} / \mathrm{m}^{3}\right)$

$A_{w}$ - windage area $\left(\mathrm{m}^{2}\right)$

$V_{w}$ - relative wind velocity $(\mathrm{m} / \mathrm{s})$

Wind drag coefficient are determined either from wind tunnel tests or Computational Fluid Dynamics (CFD) simulation. Wind force amounting few hundred tons results in high drift angles during passage through narrow fairways increasing risk of vessel grounding.
Strong lateral wind may require some increased engine power to keep vessel within the fairway limits, but at the price of increased speed and problems with safe ship handling. Excessive speed may render more difficult negotiating of tight bends, escort towing and efficiency of tunnel thrusters. Wind force acting upon moving forward vessel creates turning moment which needs to be counterbalanced with moment generated by ship's rudder as shown below:

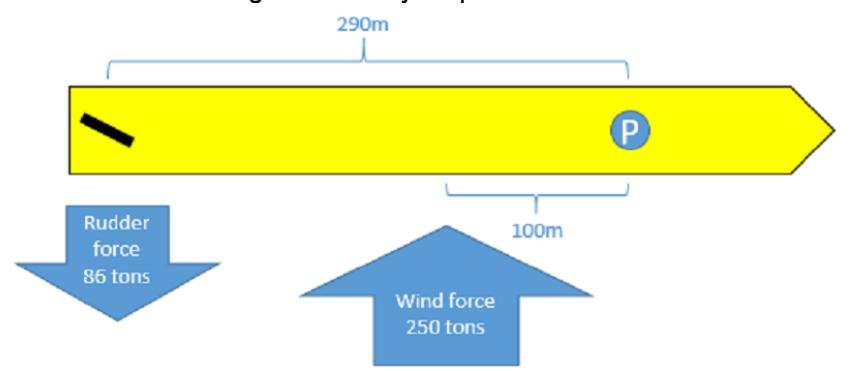

Fig. 4. Steering force generated by rudder to counter wind force. [2]

Available rudder force depends largely on engine revolutions and rudder position hard over is not sufficient to keep vessel on track, revolutions must be increased. Twin rudders arrangement of Triple-E ULCS may be advantageous in such situations as capable of generating higher lifting force than single rudder. Despite of counterbalancing of wing turning moment with rudder and movement at desired track, vessel develops certain drift angle, closely related to speed and increasing with its reduction. Excessive drift angle leads to risk of vessel grounding when askew movement brings bow or stern close to fairway limit. Table below presents some values of wind generated forces and drift angles for typical ULCS's:

Tab. 1. Angle of drift and wind induced force. Modified from: [3]

\begin{tabular}{|l|c|c|c|}
\hline \hline \multicolumn{4}{|c|}{ Wind abeam } \\
\hline Draft m & 11 & 13 & Triple-E, 11 \\
\hline Lateral Area $\mathrm{m}^{2}$ & 14000 & 14000 & 18000 \\
\hline Wind velocity m/s & 18 & 18 & 18 \\
\hline Wind induced force t & 250 & 250 & 325 \\
\hline Speed 12 knots drift angle & $3^{\circ}$ & $2^{\circ}$ & $4^{\circ}$ \\
\hline Speed 9 knots drift angle & $4^{\circ}$ & $4^{\circ}$ & $6^{\circ}$ \\
\hline Speed 6 knots drift angle & $10^{\circ *}$ & $7^{\circ *}$ & $9^{\circ *}$ \\
\hline \multicolumn{4}{|c|}{${ }^{\circ}$ Necessity to increase engine power to keep the course } \\
\hline
\end{tabular}

Vessels moving along entry fairway to The Outer Port of Gdańsk tend to move with slower speed, approximately 4 knots, with further reduction while entering harbour basin. At this speed, with wind force $7^{\circ}$, vessel alone becomes unmanageable and escort towing fore and aft with another tugboats available for pushing is required. In case of lateral current of $1 \mathrm{knot}$, another few hundred tons may add to wind induced force and available power from thrusters and tugboats could be insufficient. Such currents were recorded in south-eastern part of Gulf of Gdańsk but probability of their occurrence is low.

\section{Wind factor while mooring.}

During mooring/unmooring operations in DCT, ULCS is restricted in use manoeuvring thrusters and main propulsion in close proximity to the quay to avoid its damage. Usage of thrusters is limited to bare essentials for sake of safety. Worst case scenario is with wind abeam to vessel and exerting lateral force few hundred tons. Safe operation can be carried on when summary force of available tugboats and, when necessary, thrusters is exceeding wind lateral force. To provide safety margin for unexpected wind gusts, total calculated force provided by tugboats and thrusters should exceed 
wind induced force at least for $25 \%$. Figure 5 shows forces acting upon vessel during mooring operations.

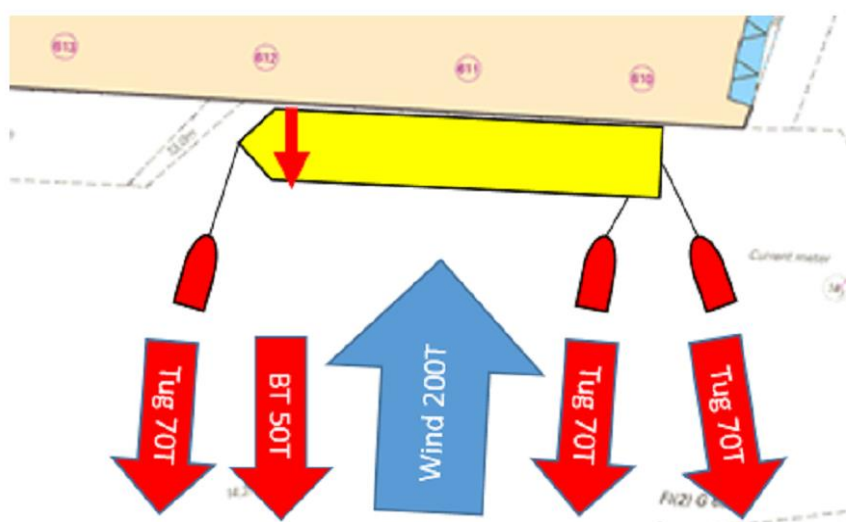

Fig. 5. Forces acting during mooring/unmooring operations in windy conditions. [3]

\section{Current factor}

Sea current is rare occurrence at approach fairway to DCT but must also be taken under consideration when analysing safety of port entry operations. Generally lateral force induced upon vessel can be calculated with the following formula [2]:

$$
F=1 / 2 \bullet \rho_{w} \bullet C_{c} \bullet L \bullet T \bullet V_{c}^{2}
$$

Where:

$$
\begin{aligned}
& \mathrm{F} \text { - lateral current force }(\mathrm{N}) \\
& \mathrm{C}_{c}-\text { current drag coefficient } \\
& P_{\mathrm{w}}-\text { water density }\left(\mathrm{kg} / \mathrm{m}^{3}\right) \\
& \mathrm{L}-\text { vessel length }(\mathrm{m}) \\
& \mathrm{T}-\text { vessel draft }(\mathrm{m}) \\
& \mathrm{V}_{c}-\text { current velocity }(\mathrm{m} / \mathrm{s})
\end{aligned}
$$

Above formula works well for water depth exceeding five ship drafts which is widely accepted definition of deep water. Decreased under keel clearance becomes restriction accelerating water flow under the hull and building up pressure on the exposed side. Amount of force exerted by current rises sharply with diminishing under keel clearance Formula given above provides force exerted by abeam current at deep water but doesn't take into consideration under-keel clearance. For practical purposes another formula may be used yielding result in tons [2]:

$$
F=f \bullet L \bullet T \bullet V_{c}^{2}
$$

Where:

$$
\begin{aligned}
& F \text { - lateral current force }(t) \\
& f \text { - coefficient depending on under-keel clearance } \\
& L \text { - vessel length }(m) \\
& T \text { - vessel draft }(m) \\
& V_{c}-\text { current velocity }(k n)
\end{aligned}
$$

Above given formula provides fairly good estimation of current induced lateral force for calculation of amount of tugs necessary for safe conduct of mooring operations and for calculation drift angle in narrow fairway. Coefficient for given formula can be obtained from graph shown by figure 6 :

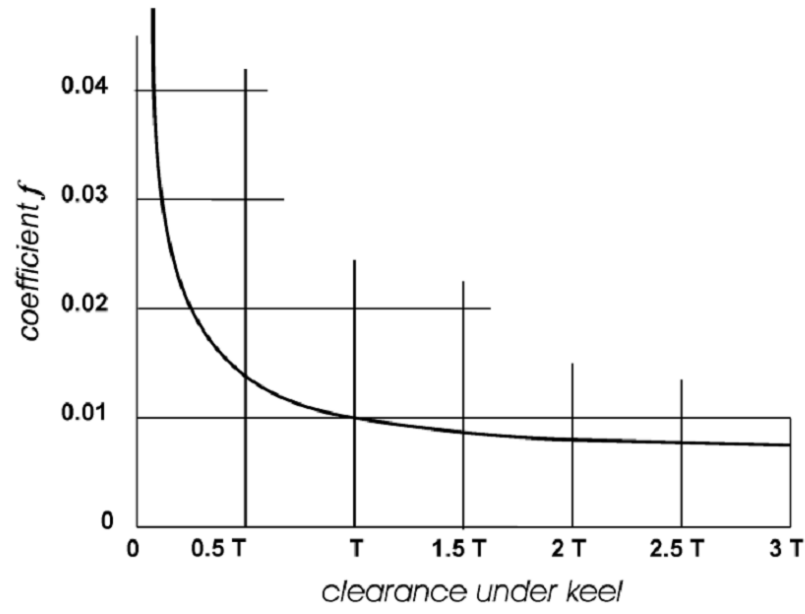

Fig. 6. Graph for estimation of $f$ coefficient for use with practical formula (3). [2]

Calculation conducted with more advanced method [1] are showing strong correlation with simplified method described above. Calculated values for four different scenarios are presented on figure 7 in a graphic form

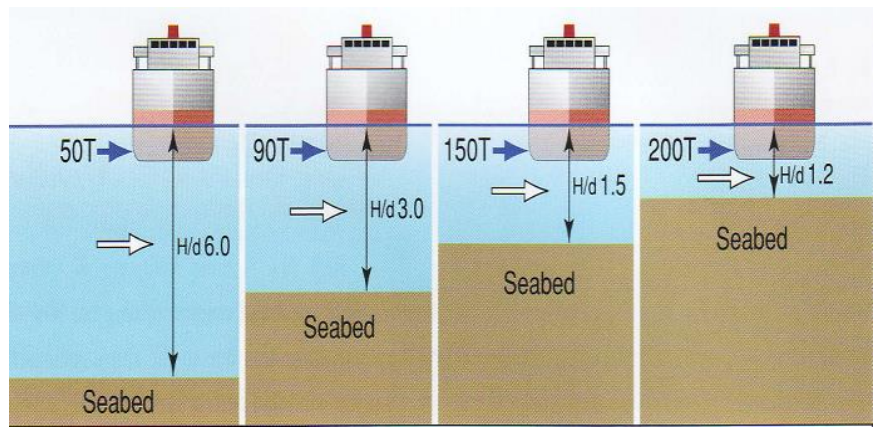

Fig. 7. Current induced lateral force in relation to under keel clearance for lateral current 1 knot. [1]

Forces generated by current for last two scenarios are comparable to these induced by wind and should be taken into consideration for planning of mooring operations and risk assessment. Both these scenarios are typical for handling vessels in port and at approach fairways. Coincidence of both factors may lead to loss of control when handling ULCS.

\section{Conclusion}

Pursuit to lower transportation cost has led to construction of ultra large container vessels wit length $400 \mathrm{~m}$ and capable of carriage of 18,000 TEU. Such vessels providing long range service between Far East and European ports. Handling new generation of container vessels encounters several problems due to their extremely large wind exposed area and deep draft. Port of Gdańsk is now routinely receiving. Safe handling of such large vessels depends on analysis of factors which may lead to loss of control over ship during port entry and mooring operations. Strong lateral wind is one of the most significant factors. It can generate lateral force amounting several hundred tons which may cause excessive drift whilst negotiating narrow channel and bends. Undesirable moment created by wind induced force must be compensated by ship's rudder adequate main engine revolutions, with tugs assistance. Mooring operations require tugs with sufficient power to overcome wind pressure. In course of several simulation tests, wind force $7^{\circ}$ Beauforta was found as upper safe limit for mooring operations in DCT when handling ULCS. Impact of sea current upon safety of mooring operation 
was not included in related studies due to rare occurrence of weak current with speed not exceeding one knot. However even such may generate forces similar to these induced by strong wind. Unfortunate coincidence of both factors seriously affect safety of handling of ULCS.

Bibliography:

1. A Guide to Ship Handling, Japan Captain's Association, Tokyo 2014

2. Manned Model Ship Handling Course, Trainee Handout, Ship Handling and Research Centre, Iława 2017

3. Sjöberg H., et al., Safe Handling of Ultra Large Container Ships in Strong Wind, Gothenburg, 2016

4. Śniegocki $H_{\text {., }}$ et al., Badanie symulacyjne toru podejściowego oraz cumowania statku klasy Triple $E$ do planowanego nabrzeża DCT Gdańsk S.A, Akademia Morska w Gdyni, Gdynia 2012

5. https://photos.fleetmon.com/vessels/maersk-mc-kinneymller_9619907_649423_XLarge.jpg, accesed 16.11.2018

6. https://www.portgdansk.pl/about-port/development-plans, accesed 16.11.2018

\section{Czynniki wpływające na bezpieczeństwo manewrowania bardzo dużymi kontenerowcami w porcie Gdańsk}

W artykule omówiono ważne czynniki wpływające na manewrowanie dużymi kontenerowcami w porcie gdańskim. W ostatnich latach coraz więcej takich statków zawijało do portu w Gdańsku, włączając w to nowa generację ultra dużych kontenerowców typu Triple-E, zbudowana dla firmy Maersk. Badania przeprowadzone na Uniwersytecie Morskim w Gdyni potwierdziły możliwość bezpiecznego manewrowania takimi statkami, ale wskazały na szereg czynników, które powinny być uwzględnione w celu zapewnienia odpowiedniego poziomu bezpieczeństwa operacjom manewrowania statkami. Autorzy przeanalizowali czynniki odpowiedzialne za bezpieczne manewrowanie dużymi kontenerowcami w porcie gdańskim.

Słowa kluczowe: kontenerowiec, Gdańsk, manewrowanie..

Authors:

Jan Pawelski PhD, Master Mariner, OIM - Maritime University of Gdynia

Wiesław Piotrzkowski MSc. Master Mariner - Maritime Office of Gdynia of Gdynia

Henryk Śniegocki DSc, Master Mariner- Maritime University

Przemysław Wilczyński PhD, Master Mariner - Maritime University of Gdynia 